Pesq. Vet. Bras. 37(1):23-30, janeiro 2017 DOI: $10.1590 / \mathrm{S} 0100-736 \mathrm{X} 2017000100004$

\title{
Experimental poisoning by Enterolobium contortisiliquum in sheep ${ }^{1}$
}

\author{
Flávia Barbieri Bacha², Rayane Chitolina Pupin², Paula Velozo Leal², Nilton Marques \\ Carvalho $^{2}$, Gumercindo Loriano Franco ${ }^{2}$, Camila Celeste Brandão Ferreira Ítavo², \\ Franklin Riet-Correa ${ }^{4,5}$ and Ricardo Antônio Amaral de Lemos ${ }^{3 *}$
}

\begin{abstract}
Bacha F.B., Pupin R.C., Leal P.V., Carvalho N.M., Franco G.L., Ítavo C.C.B.F., Riet-Correa F. \& Lemos R.A.A. 2017. Experimental poisoning by Enterolobium contortisiliquum in sheep. Pesquisa Veterinária Brasileira 37(1):23-30. Laboratório de Anatomia Patológica, Faculdade de Medicina Veterinária e Zootecnia, Universidade Federal de Mato Grosso do Sul, Avenida Senador Filinto Müller 2443, Campo Grande, MS 79074-460, Brazil. E-mail: ricardo.lemos@ufms.br

Ingestion of Enterolobium contortisiliquum pods causes digestive disturbances, secondary hepatogenous photosensitization and abortions in ruminants. Pods were administered to sheep via a ruminal cannula to characterize acute poisoning. In Experiment 1, a single dose of $12 \mathrm{~g} / \mathrm{kg}$ of body weight (BW) was administered to three sheep in one experiment. One sheep died, and the other two recovered after presenting clinical signs. In Experiment 2, $10 \mathrm{~g} / \mathrm{kg}$ BW were administered daily to 15 sheep until the onset of clinical signs or for three consecutive days. Fourteen sheep showed mild to severe signs after the ingestion of 1-3 doses. Two sheep died, and the others recovered. Clinical signs in both experiments were diarrhea, anorexia, rumen atony, apathy, dehydration and tachypnea. The main macroscopic findings were an orange, frothy ruminal content witch contained pods fragments. The intestinal content was liquid. Detachment of the mucosa from the submucosa and ballooning degeneration of mucosal cells were observed histologically in the forestomachs. Evaluation of ruminal contents revealed acute lactic ruminal acidosis (ALRA). Bromatological analysis of $E$. contortisiliquum pods revealed $537.8 \mathrm{~g} / \mathrm{kg}$ DM (dry matter) of non-fibrous carbohydrates, which is sufficient to cause ALRA. Only one sheep in Experiment 2 had liver failure, characterized by jaundice, elevated serum activity of liver enzymes and histological lesions in liver biopsies. It is concluded that the administration of E. contortisiliquum pods in forage-fed sheep at doses of $10 \mathrm{~g} / \mathrm{kg}$ BW or higher may cause ALRA. The induction of liver failure in one sheep suggests that liver damage may occur in those sheep that do not develop acidosis.

INDEX TERMS: Poisonous plants, Enterolobium contortisiliquum, Leg. Mimosoideae, sheep, plant poisoning, acute lactic ruminal acidosis, sheep diseases, photosensitivity.
\end{abstract}

RESUMO.- [Intoxicação experimental por Enterolobium contortisiliquum em ovinos.] A ingestão das favas de Enterolobium contortisiliquum causa distúrbios digestivos,

\footnotetext{
${ }^{1}$ Received on July 3, 2015.

Accepted for publication on August 30, 2016.

${ }^{2}$ Curso de Zootecnia, Faculdade de Medicina Veterinária e Zootecnia (FAMEZ), Universidade Federal de Mato Grosso do Sul (UFMS), Av. Senador Filinto Müller 2443, Campo Grande, MS 79074-460, Brazil.

${ }^{3}$ Laboratório de Anatomia Patológica, FAMEZ-UFMS, Av. Senador Filinto Müller 2443, Campo Grande, MS 79074-460, Brazil. *Corresponding author: ricardo.lemos@ufms.br

${ }^{4}$ Hospital Veterinário, Universidade Federal de Campina Grande (UFCG), Patos, PB 58700-000, Brazil.

${ }^{5}$ National Institute of Agricultural Research (INIA), La Estanzuela, C.P. 70.000 Colonia, Uruguay.
}

fotossensibilização hepatógena e abortos em ruminantes. Para caracterizar a intoxicação aguda, favas de E. contortisiliquum foram administradas a ovinos por meio de cânula ruminal. No Experimento 1, uma dose única de $12 \mathrm{~g} / \mathrm{kg}$ de peso corporal (pc) foi administrada a três ovinos. Um dos ovinos morreu e os outros dois se recuperaram após mostrar sinais clínicos. No experimento $2,10 \mathrm{~g} / \mathrm{kg} / \mathrm{pc}$ foram administradas diariamente a 15 ovinos, por três dias consecutivos ou até o parecimento dos sinais clínicos. Catorze ovinos mostraram sinais clínicos leves a acentuados após ingestão de 1-3 doses. Dois ovinos morreram e os outros se recuperaram. Observou-se nos ovinos dos experimentos 1 e 2, diarreia, anorexia, atonia ruminal, apatia, desidratação e taquipneia. Os principais achados macroscópicos incluíram conteúdo ruminal espumoso e alaranjado em meio 
ao qual se observavam fragmentos das favas de E. contortisiliquum, e conteúdo intestinal líquido. Histologicamente, havia degeneração balonosa e desprendimento do epitélio de revestimento dos pré-estomagos. A avaliação do conteúdo ruminal revelou acidose ruminal láctica aguda (ARLA). Análise bromatológica das favas de E. contortisiliquum revelou $537.8 \mathrm{~g} / \mathrm{kg}$ de matéria seca de carboidratos não fibrosos, quantidade suficiente para causar ARLA. Um ovino do Experimento 2 teve insuficiência hepática aguda, caracterizada por icterícia, elevação da atividade sérica das enzimas hepáticas e alterações histológicas observadas em biópsia hepática. Concluiu-se que a administração de favas de $E$. contortisiliquum na alimentação de ovinos, nas doses de $10 \mathrm{~g} / \mathrm{kg}$ pc ou maiores, pode causar ARLA. A ocorrência de insuficiência hepática num dos ovinos deste experimento sugere que a lesão hepática pode se desenvolver em ovinos que não apresentam ARLA.
TERMOS DE INDEXAÇÃO: Plantas tóxicas, Enterolobium contortisiliquum, Leg. Mimosoideae, ovinos, intoxocação por planta, acidose ruminal láctica aguda, fotossensibilização.

\section{INTRODUCTION}

Enterolobium contortisiliquum (Vell.) Morong (Leguminosae-Mimosoideae) (Fig.1), coloqually known as "tamboril", "orelha-de-macaco" (Lorenzi 1992) and "ximbuva" (Pott \& Pott 1994), is a tree that is widely found in Brazil (Tokarnia et al. 2012). Fruiting of this tree spans from June to July. Pods that fall spontaneously and pods attached to wind-fallen or pruned branches or lodged in intact plants are ingested by livestock, which may cause poisoning (Méndez \& Riet-Correa 2007, Riet-Correa et al. 2011). Spontaneous intoxication was reported in cattle (Grecco et al. 2002, Mendonça et al. 2009), sheep (Bezerra et al. 2012) and goats (Benicio et al. 2007). The toxic active compound, appa-
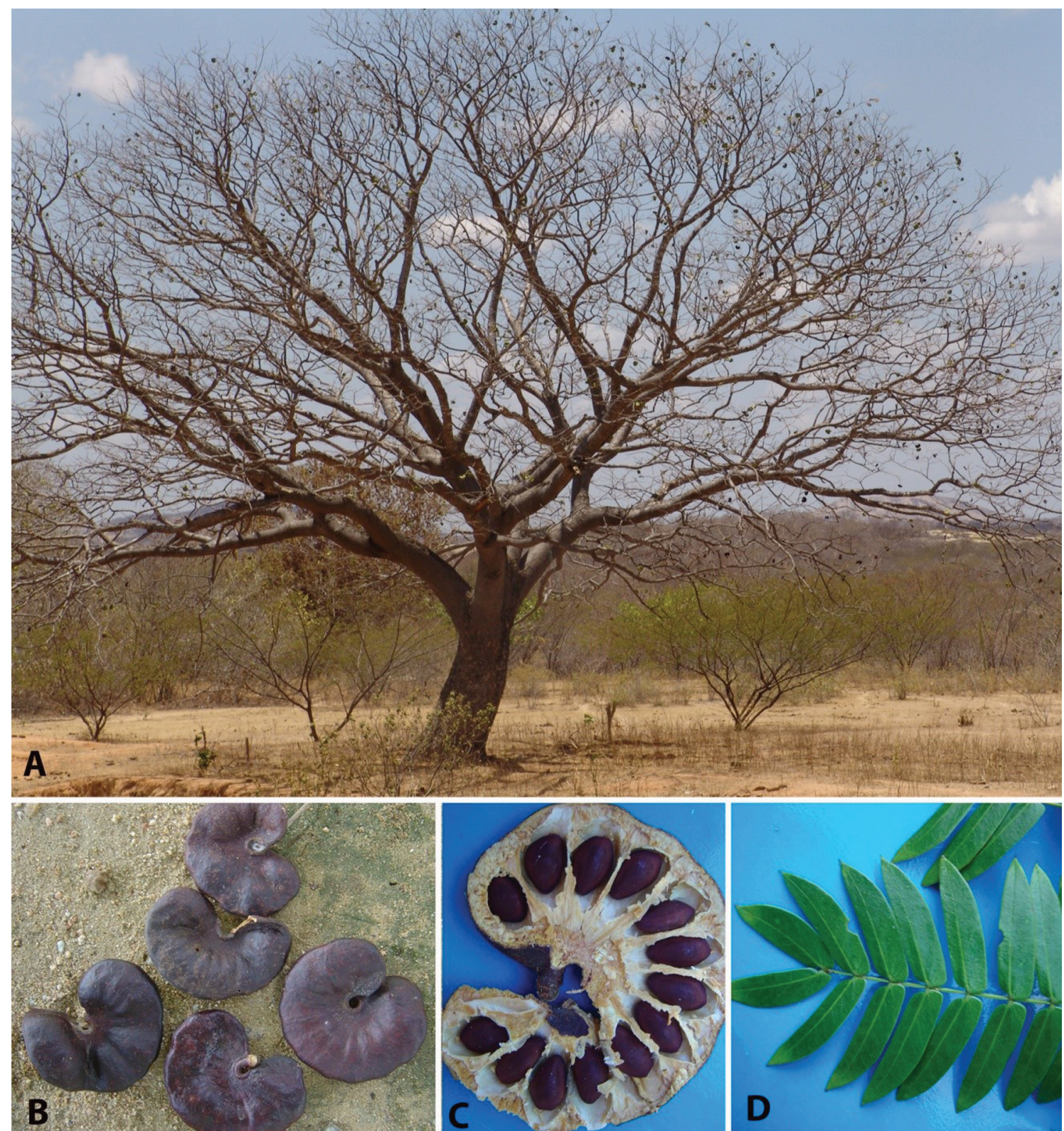

Fig.1. Enterolobium contortisiliquum. (A) Tree. (B) Pods on the ground. (C) An open pod with the seeds inside. (D) Leaves. 
rently, consists of saponins, which are toxic to macrophages and lymphocytes (Mimaki et al. 2003, 2004).

Only mild photodermatitis was already reproduced experimentally (Grecco et al. 2002), despite the epidemiological evidence that implicates this plant specie in hepatogenous photosensitization and abortion (Tokarnia et al. 1999). The abortive properties of this plant were only demonstrated in guinea pigs (Bonel-Raposo et al. 2008). Experiments in cattle reproduced acute digestive signs (Tokarnia et al. 1999, Mendonça et al. 2009). The underlying mechanisms of digestive system damage have not been elucidated. Available data suggest that photosensitization ensues in cases of survival, after the ingestion of high amounts of plant material over a short period. Another possible and unstudied factor is the influence of diet on the occurrence of photosensitivity, which is a particularly relevant aspect in hepatogenous photosensitivity, because chlorophyll content in the diet can affect the manifestation of photodermatitis (Radostits et al. 2007). This study characterized the clinical and pathological picture of acute Enterolobium contortisiliquum pods intoxication in sheep fed with forage from different sources.

\section{MATERIALS AND METHODS}

The Ethics Committee on Animal Experimentation (CEUA) of UFMS approved the experimental protocol of this study (Protocol \#400/2012). Pods of Enterolobium contortisiliquum (Vell.) Morong. were collected from trees located at 20²9'59.2"S, $55^{\circ} 47^{\prime} 27.8^{\prime \prime} \mathrm{W}$ in Anastácio county, MatoGrosso do Sul state, midwestern Brazil, in September 2013 (Fig.1). Pods were stored in cloth bags, in a dry and ventilated environment until the beginning of the experiment. Plant samples were shipped to the Botany Laboratory of the Universidade Federal de Mato Grosso do Sul (UFMS) for identification and classification. A voucher specimen was deposited (\# 44247) at the CGMS Herbarium of the UFMS.

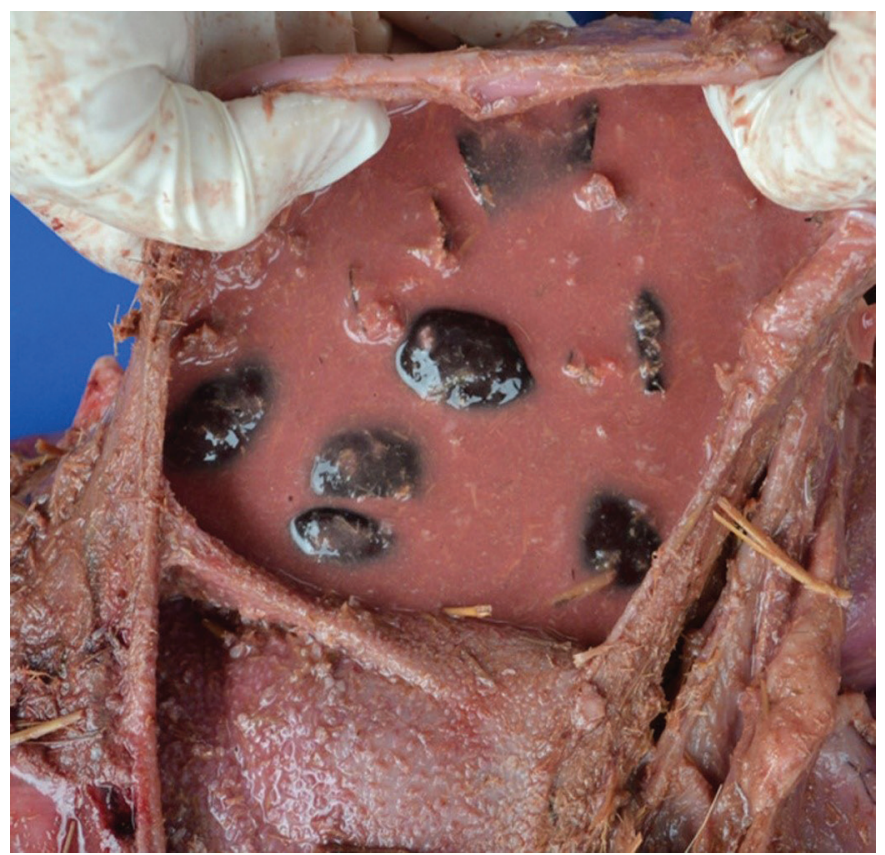

Fig.2. Experimental poisoning by Enterolobium contortisiliquum in sheep. Orange ruminal fluid in the reticulum containing broken pods.

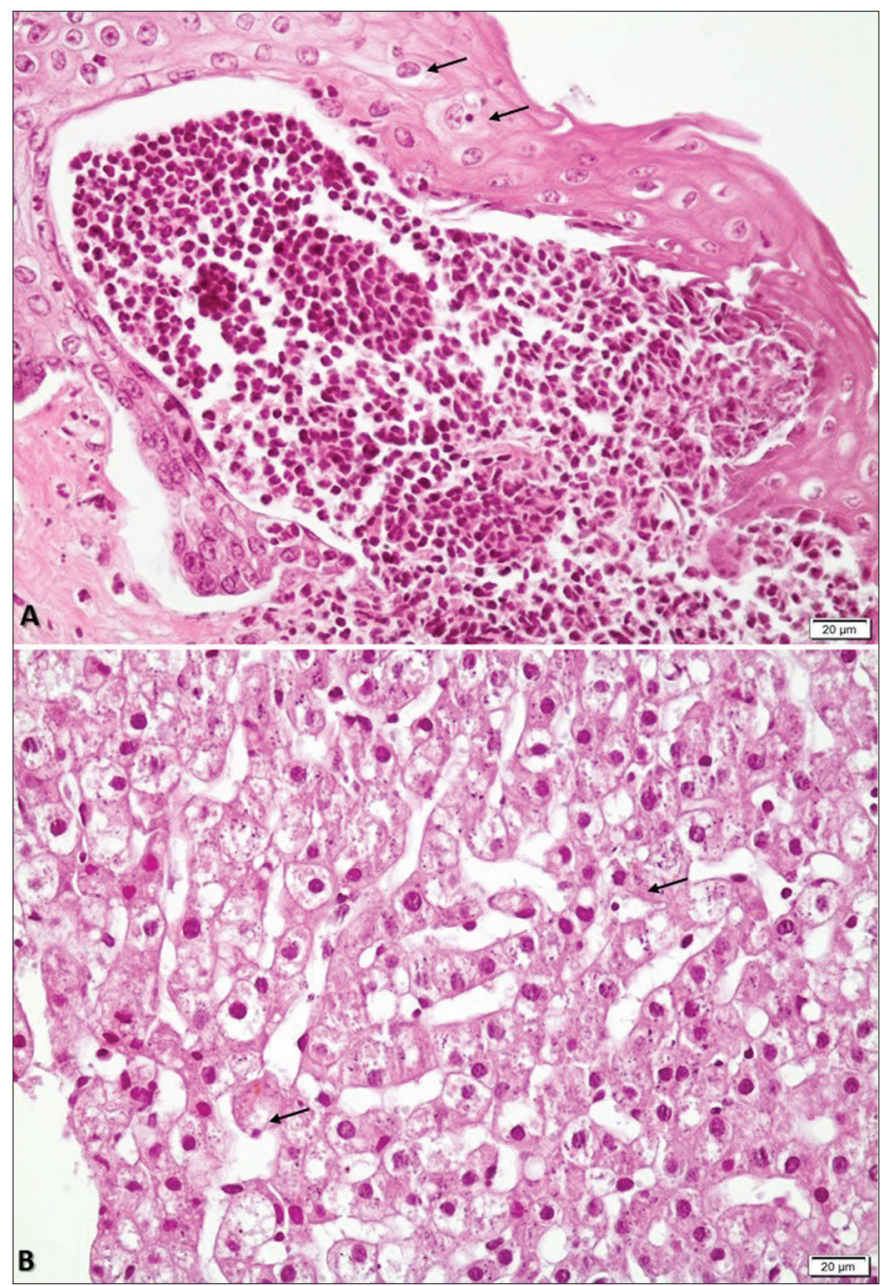

Fig.3. Sheep experimentally poisoned with Enterolobium contortisiliquum. (A) Rumen showing ballooning degeneration of the mucosal cells (black arrows) with cellular debris, necrosis and the presence of neutrophils. HE, obj.20x. (B) Liver with discrete bile retention (black arrows), moderate and diffuse hydropic degeneration of hepatocytes, slight fatty degeneration in some hepatocytes and discrete infiltrates of neutrophils. HE, obj.20x.

Sample pods, for bromatological analyses, were dried at $55^{\circ} \mathrm{C}$ for $72 \mathrm{~h}$ in a forced-air ventilation oven and subsequently ground in a mill through a 1-mm mesh screen. Bromatological analyses included quantification of dry matter (DM), organic matter (OM), mineral matter (MM), crude protein (CP), ether extract (EE), neutral detergent fiber (NDF), acid detergent fiber (ADF) and lignin (LIG), according to AOAC (2000) methods 930.15 and 976.05. NDF and ADF were determined according to Goering \& Van Soest (1970), without thermostable amylase or sulfite. Total carbohydrate (TC) content was calculated using the equation $\mathrm{TC}=$ $100-(\% \mathrm{CP}+\% \mathrm{EE}+\% \mathrm{MM})$. Non-fiber carbohydrates (NFC) were calculated as proposed by Sniffen et al. (1992), using the equation NFC $=$ TC - NDF.

Eighteen male and female mixed-breed sheep aged 12-24 months, weighing 29-59 kg, were identified using numbered neck tags. Three sheep were randomly assigned to experiment 1 , and the remaining 15 sheep were assigned to Experiment 2. Pods, in both experiments, were manually broken into triangular pieces measuring approximately $2 \mathrm{~cm} \times 1 \mathrm{~cm} \times 2 \mathrm{~cm}$, which were subsequently administered to sheep via a ruminal cannula. Sheep from Experiment 1 received a single dose of $12 \mathrm{~g} / \mathrm{kg}$ BW of pods to de- 
termine a non-lethal single dose that could be administered repeatedly. A dose of $10 \mathrm{~g} / \mathrm{kg}$ BW was administered daily to sheep from Experiment 2 until the onset of clinical signs or for three consecutive days.

All animals were raised on Brachiaria decumbens pastures and given mineral salt formulated for sheep before the experiment. The sheep were transferred to the experiment site seven days before the start of the experiment and fed the experimental diets devoid of test plant. The animals underwent $24 \mathrm{~h}$ fasting before administration of the test plant.

The 15 sheep in Experiment 2 were divided into 3 groups of 5 sheep each to identify the effect of dietary chlorophyll amounts on hepatogenous photosensitivity. Group A was fed with fresh Napier grass (Pennisetum purpureum Schum. cv. Napier) mixed with sugarcane molasses. Group B was given Tifton 85 (Cynodon dactylon) hay, and Group $\mathrm{C}$ was kept in paddocks with Brachiaria decumbens and B. brizantha. Groups A and B were housed in unroofed $4 \mathrm{~m} \times 4 \mathrm{~m}$ sand-bedded pens that allowed free exposure to sunlight. Group $\mathrm{C}$ was allowed to roam in a pasture. Table 1 depicts the experimental design.

The animals were observed daily for clinical signs of poisoning and underwent physical and parasitological evaluations. Blood samples were collected daily to evaluate the liver enzymes aspartate aminotransferase (AST) and $\gamma$-glutamyltransferase (GGT) and the jaundice index. Liver biopsy fragments were subjected to histological examination in Experiment 2. Three liver biopsies were performed on each sheep, immediately before the first administration of pods and on the 5th and 9th subsequent days. The pH-Fix 0-14 test strips (Macherey-Nagel) were employed to measure ruminal $\mathrm{pH}$ in the second experiment immediately before the first administration of pods (day 0) and every $24 \mathrm{~h}$ thereafter for 7 days. The test strips were calibrated before measurements using a digital potentiometer. Ruminal content was fully evaluated in 9 of the 15 sheep in Experiment 2 (Mendonça \& Afonso 2007). Severe cases of sheep presenting digestive disorders that lasted longer than 2 days were treated with sodium bicarbonate $(0.5 \mathrm{~g} / \mathrm{kg} \mathrm{BW})$ and transfaunation. The animals that died were necropsied. Organ fragments were fixed in $10 \%$ formalin, processed for routine histopathology, and stained with hematoxylin-eosin. The $\mathrm{pH}$ was measured via immersion of a test strip into the ruminal content during necropsy.

\section{RESULTS}

\section{Experiment 1}

The three sheep in Experiment 1 showed mild to severe digestive disorders from 18 to $24 \mathrm{~h}$ after the administration of a single dose of $12 \mathrm{~g} / \mathrm{kg}$ BW. A severe condition that led to death in 6 h developed in Sheep 2. Sheep 1 and 3 showed mild clinical signs followed by recovery. The clinical picture included apathy, decreased appetite, inappetence and liquid ruminal content. Serum activities of AST and GGT remained within reference values.

Macroscopic changes in Sheep 2 consisted of congested ocular mucosa, cyanotic oral mucosa, diffusely dark red, non-collapsed lungs, diffusely dark red kidneys, ruminal content orange with fragmented pods (Fig.2), liquid cecum content. Major microscopic changes in the rumen and omasum were a mild to severe detachment of the mucosa from the submucosa and a ballooning degeneration of mucosal cells with cellular debris, necrosis and the presence of neutrophils (Fig.3A). Moderate, diffuse swelling and the formation of well-defined vacuoles were observed in the cytoplasm of hepatocytes. The lungs were congested with severe diffuse edema.

\section{Experiment 2}

Fourteen sheep in Experiment 2 exhibited clinical signs that ranged from mild (Sheep 8, 9, 12, 13 and 16) to moderate or severe followed by recovery (Sheep 6, 7, 11, 14, 17,10 and 18), or severe followed by death (Sheep 4 and 15). The onset of clinical signs in Sheep 6, 15, 17 and 18 following a single dose, occurred between 12 and $18 \mathrm{~h}$ after administration. Clinical signs in Sheep 4, 10, 11 and 12 appeared between 12 and $24 \mathrm{~h}$ after administration of the second dose. Clinical signs in Sheep 7, 8, 9, 13, 14 and 16

Table 1. Experiment 2. Body weight, number of doses and total dose administered, severity of clinical signs, time elapsed between administration of Enterolobium contortisiliquum pods and the onset of clinical signs, clinical course, and outcome of induced intoxication in sheep

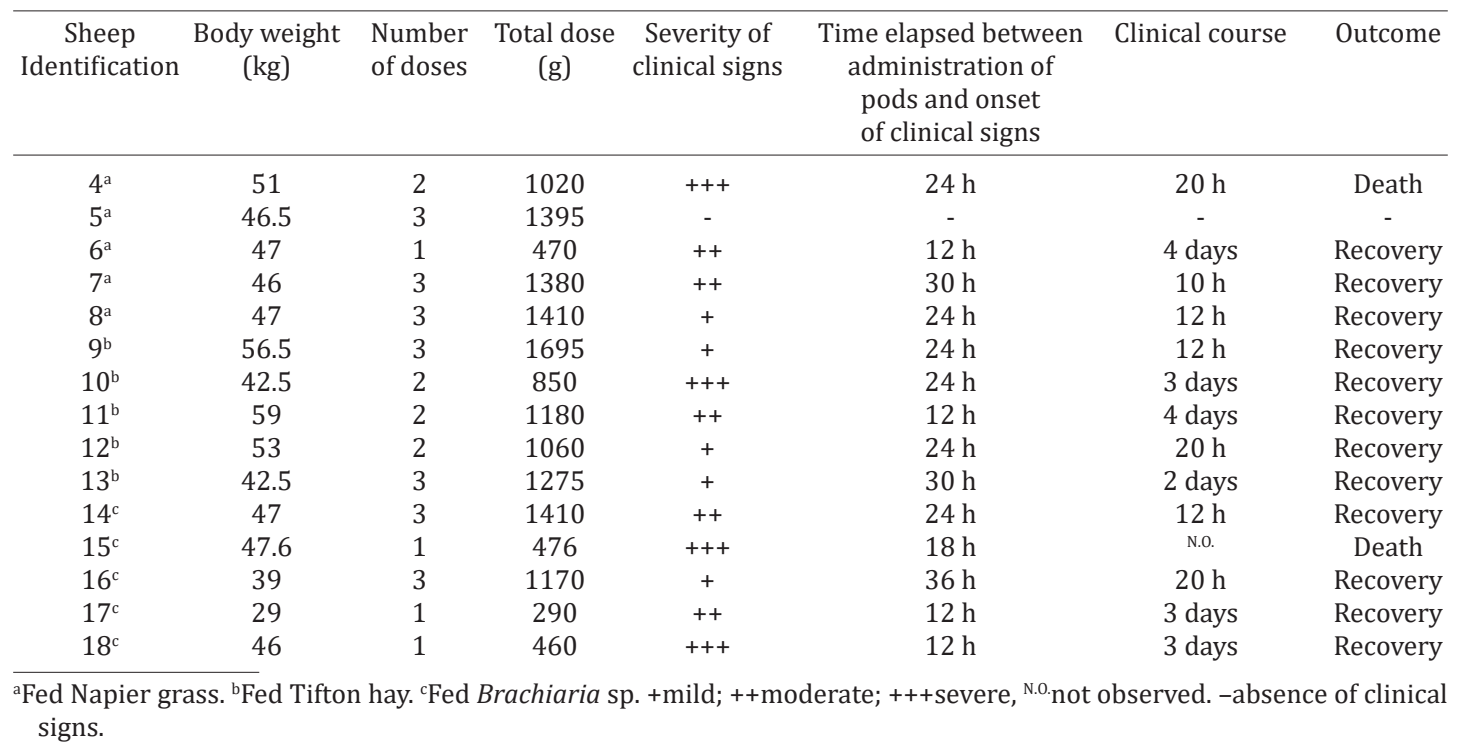


Table 2. Values of pH measured every $24 \mathrm{~h}$ in Experiment 2, induction of intoxication by Enterolobium contortisiliquum

\begin{tabular}{|c|c|c|c|c|c|c|}
\hline Sheep identification & $\mathrm{pH}, 0 \mathrm{~h}$ & $\mathrm{pH}, 24 \mathrm{~h}$ & $\mathrm{pH}, 48 \mathrm{~h}$ & $\mathrm{pH}, 72 \mathrm{~h}$ & Severity of clinical signs & Outcome \\
\hline 4 & 7.0 & 5.5 & - & - & +++ & Death \\
\hline 5 & 7.0 & 6.0 & 7.0 & 6.0 & - & - \\
\hline 6 & 7.0 & 6.0 & 6.0 & 6.5 & ++ & Recovery \\
\hline 7 & 7.0 & 6.0 & 7.0 & 7.0 & ++ & Recovery \\
\hline 8 & 7.0 & 6.5 & 7.0 & 7.0 & + & Recovery \\
\hline 9 & 7.0 & 5.5 & 6.0 & 7.0 & + & Recovery \\
\hline 10 & 6.5 & 6.0 & 5.0 & 7.0 & +++ & Recovery \\
\hline 11 & 6.5 & 6.0 & 5.0 & 6.0 & ++ & Recovery \\
\hline 12 & 6.5 & 6.0 & 6.0 & 6.0 & + & Recovery \\
\hline 13 & 7.5 & 6.5 & 6.0 & 6.0 & + & Recovery \\
\hline 14 & 8.0 & 6.0 & 6.0 & 7.0 & ++ & Recovery \\
\hline 15 & 7.0 & $5.0^{\mathrm{N}}$ & - & - & +++ & Death \\
\hline 16 & 7.0 & 5.0 & 6.5 & 6.0 & + & Recovery \\
\hline 17 & 7.0 & 6.0 & 6.0 & 7.0 & ++ & Recovery \\
\hline 18 & 7.0 & 5.0 & 6.5 & 6.5 & +++ & Recovery \\
\hline
\end{tabular}

${ }^{\mathrm{N} N e c r o p s y}$ time; -absence of clinical signs.

Table 3. Experiment 2. Evaluation of ruminal contents on day 3 of experimental intoxication by Enterolobium contortisiliquum

\begin{tabular}{|c|c|c|c|c|c|c|}
\hline $\begin{array}{l}\text { Severity of } \\
\text { clinical signs }\end{array}$ & $\begin{array}{l}\text { Number } \\
\text { of ovines }\end{array}$ & Color & Consistency & Odor & $\begin{array}{c}\text { Sedimentation } \\
\text { time }\end{array}$ & $\begin{array}{l}\text { Methylene } \\
\text { blue }\end{array}$ \\
\hline Severe & 2 & $\begin{array}{l}\text { Brownish, } \\
\text { hemorrhagic }\end{array}$ & Aqueous & Putrid & $>8 \min$ & $>8 \min$ \\
\hline Moderate & 3 & Brownish & Aqueous/viscous & Acid & $<8 \min$ & $<8 \min$ \\
\hline Mild & 3 & Olive green & Viscous & Aromatic & $<8 \min$ & $<8 \mathrm{~min}$ \\
\hline
\end{tabular}

appeared between 24 and $36 \mathrm{~h}$ after the third dose. Twelve sheep recovered, and 2 sheep died. No clinical or pathological differences were found among groups A, B and C. No clinical signs were observed in Sheep 5.

Clinical signs were similar across groups, except for Sheep 6, and these signs varied only in intensity. Clinical signs predominantly consisted of digestive disorders, including diarrhea, decreased appetite, rumen atony and a liquid, frothy ruminal content, in addition to apathy, dehydration and tachypnea. Pods fragments that were expelled during rumination were found on stall floors. Sheep 10 and 11 fully recovered after treatment. Overall, changes in ruminal content varied with the severity of clinical signs, irrespective of diet. Moderate reddening of the ruminal mucosa was observed in animals with severe manifestations during the collection of ruminal content. Table 1 shows the severity of clinical signs, time elapsed from pod administration to the onset of clinical signs, clinical course and outcomes in Experiment 2. Table 2 shows variations in $\mathrm{pH}$ after pod administration and the relationship with the occurrence and intensity of clinical manifestations and evolution. Tables 3 and 4 depict the results of ruminal content evaluations of the 9sheep included in Experiment 2.

Sheep 6 exhibited digestive disorders similar to other sheep in the same group after the first dose, but this animal manifested moderate jaundice for 5 days from the second day onwards, concurrently with digestive signs. Clinical manifestations were accompanied with elevated activities of serum liver enzymes that ranged from 99 to $853 \mathrm{IU} / \mathrm{L}$ for AST and 61 to 329 IU/L for GGT. These enzymes remained within normal ranges (60-280 IU for AST and 20-52 IU for GGT) in the other animals (Meyer \& Harvey 2004).
Mild bile retention, moderate diffuse hydropic degeneration of hepatocytes, mild fatty degeneration in some hepatocytes, and mild neutrophilic infiltration were observed in Sheep 6 on a liver biopsy performed in the $5^{\text {th }}$ day and, to a lesser extent, on biopsy in the $9^{\text {th }}$ day (Fig.3B). No significant lesions were observed in other animals on liver biopsies. The following similar macroscopic changes were observed

Table 4. Experiment 2. Evaluation of ruminal contents on day 3 of experimental intoxication by Enterolobium contortisiliquum

\begin{tabular}{lccccc}
\hline Severity & Number & \multicolumn{4}{c}{ Infusoria } \\
\cline { 3 - 6 } $\begin{array}{l}\text { of clinical } \\
\text { signs }\end{array}$ & of ovines & Live $\times$ dead & Motility & Size & Density \\
\hline Severe & 2 & All dead & XXX & Only small & Very low \\
Moderate & 3 & $3 \%$ & + & Only small & Low \\
Mild & 3 & $10-30 \%$ & + & Small $>$ medium $>$ large & Low
\end{tabular}

Table 5. Bromatological composition and estimated nutritional value of $E$. contortisiliquum pods

\begin{tabular}{lc}
\hline \multicolumn{1}{c}{ Variable } & Content \\
\hline Dry matter, DM (g/kg) & 852.9 \\
Mineral matter, MM (g/kg DM) & 38.1 \\
Crude protein, CP (g/kg DM) & 170.9 \\
Ether extract, EE (g/kg DM) & 10.5 \\
Neutral detergent fiber, NDF (g/kg DM) & 255.8 \\
Neutral-detergent-insoluble nitrogen, NDIN (g/kg DM) & 2.1 \\
Neutral-detergent-insoluble protein, NDIP (g/kg DM) & 13.1 \\
Neutral detergent fiber corrected for protein, NDFcp (g/kg DM) & 242.7 \\
Non-fiber carbohydrate, NFC (g/kg DM) & 537.8 \\
Total digestible nutrients, TDN (g/kg DM) & 764.0
\end{tabular}

Total carbohydrate content: TC $=100-(\% \mathrm{CP}+\% \mathrm{EE}+\% \mathrm{MM}) ; \mathrm{NFC}=\mathrm{TC}-$ NDF (Sniffen et al. 1992). 
in Sheep 4 and 15 (fatal cases): congested ocular mucosa; cyanotic oral mucosa; engorged tracheal blood vessels; diffusely dark red, non-collapsed lungs with superficial white areas; undelimited dark red areas on the parietal pleura; engorged blood vessels and undelimited dark red areas in the ruminal serosa; frothy, liquid ruminal fluid, containing broken pods; red multifocal areas in the abomasal mucosa; liquid intestinal content, especially in the cecum; liver with rounded edges, evident lobular pattern and dark red areas on the surface; diffusely dark red kidneys; spleen with rounded edges; and engorged cerebral blood vessels. $\mathrm{Ru}-$ minal pH at necropsy was 5.0 in both animals. Histological findings in the rumen and reticulum were similar to the findings in Experiment 1, but the findings extended to the omasum.The liver exhibited neutrophilic infiltration of the sinusoids and individual necrosis of hepatocytes.

Table 5 shows the bromatological composition of Enterolobium contortisiliquum seeds.

\section{DISCUSSION}

With the exception of Sheep 6 in Experiment 2, the clinical manifestations and lesions observed in both experiments were typical of acute lactic ruminal acidosis (ALRA)(NRC 2006, Zachary \& McGavin 2011). ALRA was demonstrated by the ruminal pH values in Experiment 2, i.e., pH 5 at necropsy for both fatal cases, but a pH of 5-5.5 for several surviving animals. The $\mathrm{pH}$ values below 5.5 are sufficient to cause ALRA (Dirksen 2005, Dijkstra et al. 2012, Kleen \& Cannizzo 2012). Spontaneous ALRA occurs in ruminants that are fed large amounts of NFCs (corn, wheat and barley) without previous adaptation (Ortolani 1995, Thoefner et al. 2004, Nagaraja \& Titgemeyer 2007). Streptococcus bovis was reported as the principal causative agent of ALRA because of its pronounced growth on starch-based substrates, with lactic acid the main end product of fermentation. Drops in ruminal $\mathrm{pH}$ are associated with the accumulation of lactic acid, which potentially leads to ALRA (Hobson \& Stewart 1997). Bromatological analysis of pods in the present study revealed a 1:2.2 ratio $(\mathrm{w} / \mathrm{w})$ between neutral detergent fiber corrected for protein (NDFcp) and NFC, which is much higher than the $1: 1$ ratio recommended by Poore et al. (1993) to prevent depression in fiber digestion and preserve normal rumen function. This result supports the hypothesis that fermentable carbohydrates (starches and sugars) in the NFC fraction of Enterolobium contortisiliquum pods may induce ALRA.

The diets of animals in both experiments fed Napier grass, Tifton 85 hay and Brachiaria sp. were fiber-rich and low in NFCs, and these animals underwent $24 \mathrm{~h}$ fasting before pod administration. This procedure may have promoted acidosis by arresting microorganism growth, with a resultant decrease in and loss of microorganism diversity (Mackie et al. 2002). Protocols for the experimental induction of ALRA in sheep (Afonso et al. 2005, Câmara et al. 2013), goats (Miranda Neto et al. 2005, Miranda Neto et al. 2011), and cattle (Ortolani 1995, Thoefner et al. 2004, Nagaraja \& Titgemeyer 2007) include fasting to enlarge the ruminal space before substrate administration, despite differences in only substrate type and dose. These proto- cols also require exclusive feeding on forage or diets with low levels of concentrate before the induction of acidosis to prevent increases in the population of lactate-using bacteria (Ortolani 1995, Thoefner et al. 2004, Nagaraja \& Titgemeyer 2007, Danscher et al. 2009).

Clinical signs first appeared between 18 and 24h after plant administration in Experiment 1 and between 12 and 36h in Experiment 2. These signs was observed when ruminal $\mathrm{pH}$ values are near or lower than 5.0. The time frames detected in our study corroborate with findings of several studies on experimentally induced ALRA in cattle, which reported that the onset of signs occurred between 9 and $72 \mathrm{~h}$ after induction, depending on the protocol adopted (Ortolani 1995, Brown et al. 2000, Momcilovic et al. 2000, Thoefner et al. 2004, Danscher et al. 2009, Rodrigues 2009).

Repeated low doses of E. contortisiliquum pods confer increased resistance against acute intoxication, which reveals an adaptive mechanism (Tokarnia et al. 1960, Bacha 2012). The results of the present study suggest the occurrence of this adaptation in the ruminal flora, which precluded acidosis. Diets containing high levels of concentrate allow animals to adapt to feed by increasing the ruminal populations of amylolytic microorganisms, which degrade the substrate and enable animals to process larger amounts of NFCs (Mackie et al. 2002).

The $\mathrm{pH}$ in the present study, was lower than 6.0 for all sheep that exhibited moderate to severe signs, including sheep that died. Mild signs were observed in 2 sheep with a $\mathrm{pH}$ that was 5.5 or lower. The $\mathrm{pH}$ did not reach critical values for the occurrence of ALRA in 7 animals that exhibited clinical signs. The effects of the ruminal acidosis process cannot be explained by $\mathrm{pH}$ reductions alone because the substrate also plays a role (the so-called "carbohydrate effect") (Mould \& Orskov 1984). It has been shown that 0.25 of variability that is observed in the acetate-to-propionate ratio can be attributed to $\mathrm{pH}$, and 0.75 can be attributed to diet type, which supports the assumption that, at least part of the effects observed in ALRA are not $\mathrm{pH}$-dependent, but they may be related to substrate fermentation (Calsamiglia et al. 2012). The occurrence of a toxic effect on forestomach walls, which causes rumen atony and potentially contributes to acidosis cannot be excluded in cases of the ingestion of E. contortisiliquum pods.

Pods in the present study supplied up to $234 \mathrm{~g}$ of NFC/ animal/day, which is a substantial amount of the total diet, as observed in Sheep 4. Extremely high levels of NFC, above $45-50 \%$, are associated with a higher occurrence of disorders related to ruminal acidosis, as a result of excessive rapidly fermentable carbohydrates in the rumen (pectin, starch, and sugars) (NRC 2006). Previous experiments with E. contortisiliquum pods failed to evaluate these aspects. The use of rumen cannulation in the present investigation facilitated the collection of samples for $\mathrm{pH}$ monitoring and ruminal fluid analyses.

Only Sheep 6 exhibited signs of liver dysfunction (jaundice, elevated serum GGT and AST levels, and histological changes on liver biopsy) after the manifestation of clinical signs of digestive disorders. Photosensitivity associated 
with liver damage was described in cases of spontaneous intoxication by E. contortisiliquum (Grecco et al. 2002, Mendonça et al. 2009). Although this sheep had acess to Brachiaria sp until the beginning of the experiment, clinical signs of Brachiaria poisoning were absent and the AST and GGT serum activities were within normal ranges as experimental day 0. Seven day after the acess of Brachiaria pasture has been discontinued and E. contortisiliquum administration started, clinical signs emerged simultaneously with a rise in AST and GGT serum activities. This allowed to the conclusion that clinical signs were due to E. contortisiliquum toxic action and not Brachiaria spp.

Farmers and veterinary physicians reported hepatogenous photosensitivity and abortion as the principal clinical manifestations of this type of intoxication (Tokarnia et al. 1999), however, these manifestations are rarely reproduced under experimental conditions (Tokarnia et al. 1999, Mendonça et al. 2009), or they are reproduced to a lesser extent (Grecco et al. 2002). Digestive disorders are more frequently induced (Tokarnia et al. 1999, Grecco et al. 2002, Mendonça et al. 2009). No photosensitization was observed in Sheep 6, despite the severity of liver damage, which may be because of its pigmented skin. This feature limits photodermatitis in sheep intoxicated by other photosensitizing plants (Saturnino et al. 2010). Overall, the present results suggest that liver damage in cases of spontaneous intoxication occurs when animals do not experience acidosis (because of diet type and amount of pods consumed per day), but they ingest sufficiently high doses to cause liver damage. The hepatotoxicity of E. contortisiliquum is associated with the presence of triterpene bisdesmoside saponins (enterolosaponins A, B, and C and contortisilioside B), which are toxic to macrophages and/or murine lymphoma cells (Mimaki et al. 2003, 2004).

\section{CONCLUSIONS}

The administration of Enterolobium contortisiliquum pods at doses of $10 \mathrm{~g} / \mathrm{kg}$ BW or higher after a 24 -h fast caused acute lactic ruminal acidosis in forage-fed sheep. This ALRA may be fatal if it is severe.

Liver failure was induced in one sheep under these conditions, which suggests that liver damage may occur in animals that do not develop acidosis from other types of feed.

Acknowledgements. We extend our thanks to the Coordination for the Improvement of Higher Education Personnel (CAPES) for the doctoral grant awarded to F.B.B. and the Brazilian Council for Scientific and Technological Development (CNPq, grant 14/2011, Umbrella Project 483211/2012-5) and the Brazilian Institute of Science and Technology for the Control of Plant Intoxication (INCT, grant 573534/2008-0) for their financial support.

\section{REFERENCES}

Afonso J.A.B., Kuchembuck M.R.G., Feltrin L.P.Z., Laposy C.B., Kohayagawa A., Mendonça C.L. \& Takahira R.K. 2005. Avaliação do uso da monensina sódica na prevenção da acidose láctica ruminal experimental em ovinos. Vet. Notícias 11(1):35-43.

AOAC 2000. Official Methods of Analysis of AOAC International. 17th ed. Association Official Analytical Chemists, Gaithersburg, MD, USA.

Bacha F.B. 2012. Intoxicação experimental por Enterolobium contortisiliq- uum em ovinos: caracterização clínica, patológica e efeito da adaptação ao consumo da planta. Dissertação de Mestrado em Ciência Animal, Universidade Federal de Mato Grosso do Sul, Campo Grande, MS. 38p.

Benicio T.M.A., Nardelli M.J., Nogueira F.R.B., Araújo J.A.S. \& Riet-Correa F. 2007. Intoxication by the pods of Enterolobium contortisiliquum in goats, p.67-71. In: Panter K.E., Wierenga T.L. \& Pfister J.A. (Eds), Poisonous Plants. Global Research and Solutions. CAB International, Wallingford, Oxfordshire, UK.

Bezerra C.W.C., Medeiros R.M.T., Rivero B.R.C., Dantas A.F.M. \& Riet-Correa F. 2012. Plantas tóxicas para ruminantes e equídeos da microrregião do Cariri Cearense. Ciência Rural 42(6):1070-1076.

Bonel-Raposo J., Riet-Correa F., Guim T.N., Schuch I.D., Grecco F.B. \& Fernandes C.G. 2008. Acute poisoning and abortions in guinea pigs by the pods of Enterolobium contortisiliquum (Leg. Mimosoideae). Pesq. Vet. Bras. 28(12):593-596.

Brown M.S., Krehbiel C.R., Galyean M.L., Remmenga M.D., Peters J.P., Hibbard B., Robinson J. \& Moseley W.M. 2000. Evaluation of models of acute and subacute acidosis on dry matter intake, ruminal fermentation, blood chemistry, and endocrine profile of beef steers. J. Anim. Sci. 78(12):3155-3168.

Calsamiglia S., Blanch M., Ferret A. \& Moya D. 2012. Is subacute ruminal acidosis a pH related problem? Causes and tools for its control. Annals Feed Sci. Technol. 172:42-50.

Câmara A., Afonso J.A.B., Mendonça C.L. \& Vieira A.C.S. 2013. Efeito da salinomicina na prevenção da acidose láctica ruminal experimental em ovinos. Ciênc.Anim. Bras. 14(1):65-73.

Danscher A.M., Enemark J.M.D., Telezhenko E., Capion N., Ekstrom C.T. \& Thoefner M.B. 2009. Oligofrutose overloads induces lameness in cattle. J. Dairy Sci. 92(2):607-616.

Dijkstra J., Ellis J.L., Kebreab E., Strathe A.B., López S., France J. \& Bannink A. 2012. Ruminal $\mathrm{pH}$ regulation and nutritional consequences of low $\mathrm{pH}$. Annnals Feed Sci..Technol. 172(1/2):22-33.

Dirksen G. 2005. Enfermedades de los órganos digestivos y lapared abdominal, p.325-631. In: Dirksen G., Gründer H.D. \& Stöber M. (Eds), Medicina Interna y Cirugía del Bovino. 4⿳a ed. Editorial Inter-Médica, Buenos Aires.

Goering H.K. \& Van Soest P.J. 1970. Forage Fiber Analysis (apparatus, reagents, procedures and some applications). USDA Agricultural Handbook.

Grecco F.B., Dantas A.F.M., Riet-Correa F., Leite C.G.D. \& Raposo J.B. 2002. Cattle intoxication from Enterolobium contortisiliquum pods. Vet. Human Toxicol. 44(3):160-162.

Hobson P.N. \& Stewart C.S. 1997. The rumen microbial ecosystem. Chapman and Hall, New York.

Kleen J.N. \& Cannizzo C. 2012. Incidence, prevalence and impact of SARA in dairy herds. Annals Feed Sci. Technol. 172(1/2):4-8.

Lorenzi H. 1992. Árvores Brasileiras: manual de identificação e cultivo de plantas arbóreas nativas do Brasil. Plantarum, Nova Odessa.

Mackie R.I., McSweeney C.S. \& Klieve A.V. 2002. Microbial ecology of the ovine rumen, p.71-94. In: Freer M. \& Dove H. (Eds), Sheep Nutrition. CAB International, Wallingford, UK.

Méndez M.C. \& Riet-Correa F. 2007. Intoxicação por plantas e micotoxinas, p.99-221. In: Riet-Correa F., Schild A.L., Lemos R.A.A. \& Borges J.R. (Eds), Doenças de Ruminantes e Equídeos. $3^{\underline{a}}$ ed. Pallotti, Santa Maria.

Mendonça C.L. \& Afonso J.A.B. 2007. Análise do fluido ruminal, p.308-313. In: Riet-Correa F., Schild A.L., Lemos R.A.A. \& Borges J.R. (Eds), Doenças de Ruminantes e Equideos. $3^{\underline{a}}$ ed. Pallotti, Santa Maria.

Mendonça F.S., Evêncio-Neto J., Baratella-Evêncio L., Dória R.G.S., Freitas S.H., Pelegrini L.F., Cruz R.A.S., Ferreira E.V. \& Colodel E.M. 2009. Natural and experimental poisoning of cattle by Enterolobium contortisiliquum pods (Fabaceae Mimosoideae) in Central-Western Brazil. Acta Vet. Brno 78:621-625.

Meyer D.J. \& Harvey J.W. 2004. Veterinary Laboratory Medicine: interpretation and diagnosis. 2nd ed. W.B. Saunders, Philadelphia.

Mimaki Y., Harada H., Sakuma C., Haraguchi M., Yui S., Kudo T., Yamazaki M. \& Sashida Y. 2003. Enterolosaponins A and B, novel triterpene bisdes- 
mosides from Enterolobium contortisiliquum, and evaluation for their macrophage-oriented cytotoxic activity. Bioorg. Med. Chem. Letters 13:623-627.

Mimaki Y., Harada H., Sakuma C., Haraguchi M., Yui S., Kudo T., Yamazaki M. \& Sashida Y. 2004. Contortisiliosides A-G: isolation of seven new triterpene bisdesmosides from Enterolobium contortisiliquum and their cytotoxic activity. Helv. Chim. Acta 87:851-865.

Miranda Neto E.G., Afonso J.A.B., Mendonça C.L. \& Almeida M.Z.P.R.B. 2005. Estudo clínico e características do suco ruminal de caprinos com acidose láctica induzida experimentalmente. Pesq. Vet. Bras. 25(2):73-78.

Miranda Neto E.G., Silva S.T.G., Mendonça C.L., Drummond A.R.F. \& Afonso J.A.B. 2011. Aspectos clínicos e a bioquímica ruminal de caprinos submetidos à acidose láctica experimental e suplementados ou não com monensina sódica. Pesq. Vet. Bras. 31(5):416-424.

Momcilovic D., Herbein J.H., Wittier W.D. \& Polan C.E. 2000. Metabolic alterations associated with an attempt to induce laminitis in dairy calves. J. Dairy Sci. 83(3):518-525.

Mould F.L. \& Orskov E.R. 1984. Manipulation of ruminal fluid pH and its influence on cellulolysis in sacco, dry matter degradation and the rumen microflora of sheep offered either hay or concentrate. Annals Feed Sci. Technol. 10:15-30.

Nagaraja T.G. \& Titgemeyer E.C. 2007. Ruminal acidosis in beef cattle: the current microbiological and nutritional outlook. J. Dairy Sci. 90:E17-E38.

NRC 2006. Nutrient Requirements of Small Ruminants. National Research Council, National Academy Press, Washington, DC.

Ortolani E.L. 1995. Induction of lactic acidosis in cattle with sucrose: relationship between dose, rumen fluid $\mathrm{pH}$ and animal size. Vet. Human Toxicol. 37(5):462-464.

Poore M.H., Moore J.A., Swingle R.S., Eck T.E. \& Brown W.H. 1993. Response of lactating Holstein cows to diets varying in fiber source and rumen starch degradability. J. Dairy Sci. 76:2235-2243.
Pott A. \& Pott V.J. 1994. Plantas do Pantanal. Embrapa, Corumbá.

Radostits O.M., Gay C.C., Blood D.C. \& Hinchcliff K.W. 2007. Veterinary Medicine. 10th ed. Elsevier, London. 2156p.

Riet-Correa F., Medeiros R.M.T. \& Schild A.L. 2011. A review of poisonous plants that cause reproductive failure and malformations in the ruminants of Brazil.J. Appl. Toxicol. 32(4):245-254.

Rodrigues F.A.M.L. 2009. Tratamento adicional da acidose láctica ruminal aguda em bovinos por meio de infusão de solução salina hipertônica (7,2\%). Dissertação de Mestrado em Medicina Veterinária, Faculdade de Medicina Veterinária e Zootecnia, Universidade de São Paulo, São Paulo. 118 .

Saturnino K.C., Mariani T.M., Barbosa-Ferreira M., Brum K.B., Fernandes C.E.S. \& Lemos R.A.A. 2010. Intoxicação experimental por Brachiaria decumbens em ovinos confinados. Pesq. Vet. Bras. 30(3):195-202.

Sniffen C.J., O'Connor J.D., Van Soest P.J., Fox D.G. \& Russell J.B. 1992. A net carbohydrate and protein system for evaluating cattle diets. II. Carbohydrate and protein availability. J. Anim. Sci. 70:3562-3577.

Thoefner M.B., Pollit C.C., Van Eps A.W., Milinovich G.J., Trott D.J., Wattle O. \& Andersen P.H. 2004. Acute bovine laminitis: a new induction model using alimentary oligofrutose overload. J. Dairy Sci. 87(9):2932-2940.

Tokarnia C.H., Canella C.F.C. \& Döbereiner J. 1960. Intoxicação experimental pela fava da "Timbaúba" (Enterolobium contortisiliquum (Vell.) Morong.) em bovinos. Arqs Inst. Biol. Animal, Rio de Janeiro, 3:73-81.

Tokarnia C.H., Döbereiner J., Dutra I.S., Brito I.S., Chagas B.R., França T.N. \& Brust L.A.G. 1999. Experimentos em bovinos com as favas de Enterolobium contortisiliquum e Enterolobium timbouva para verificar propriedades fotossensibilizantes e/ou abortivas. Pesq. Vet. Bras. 19(1):39-45.

Tokarnia C.H., Brito M.F., Barbosa J.D., Peixoto P.V. \& Döbereiner J. 2012. Plantas Tóxicas do Brasil. 2ª ed. Helianthus, Rio de Janeiro. 586p.

Zachary J.F. \& McGavin M.D. 2011. Pathologic Basis of Veterinary Disease. 5 th ed. Elsevier, St Louis, Missouiri. 